\title{
Analisis Faktor yang Mempengaruhi Eksistensi Ritel Tradisional di Kecamatan Sumbawa Menggunakan Structural Equation Modeling
}

\author{
Ryan Suarantalla ${ }^{1}$, Yandri Sudodo ${ }^{2}$, dan Koko Hermanto ${ }^{3}$ \\ 1,2,3 Jurusan Teknik Industri, Fakultas Teknik, Universitas Teknologi Sumbawa, \\ Jl. Raya Olat Maras ds. Batu Alang Kec. Moyo Hulu Kab. Sumbawa NTB, 84371, Indonesia \\ Email: ryan.suarantalla@uts.ac.id ${ }^{1}$, yandrisudodo@gmail.com² ${ }^{2}$ koko.hermanto@uts.ac.id ${ }^{3}$
}

DOI: 10.20961/performa.19.2.44682

\begin{abstract}
Abstrak
Saat ini, di kecamatan Sumbawa, provinsi Nusa Tenggara Barat telah banyak berdiri toko-toko ritel moderen yang menjadi pesaing bagi keberadaan ritel tradisional yang telah ada sebelumnya. Oleh karena itu tujuan dari penelitian ini adalah menganalisis faktor-faktor yang mempengaruhi eksistensi ritel tradisional dengan adanya ritel moderen di kecamatan Sumbawa. Penelitian ini menggunakan pendekatan kuantitatif dengan analisis statistika dengan menggunakan Structural Equation Modeling (SEM). Data yang digunakan pada penelitian ini adalah data primer, yaitu diperoleh melalui penyebaran kuesioner. Diketahui jumlah penduduk kecamatan Sumbawa berdasarkan data kependudukan tahun 2019 adalah 61.518 orang, sehingga dengan menggunakan rumus Slovin banyaknya sampel yang harus kuesioner untuk penelitian ini adalah minimal 100 orang (dengan tingkat error 10\%). Dari hasil analisa menggunakan SEM dan software LISREL diperoleh model matemtika untuk eksistensi ritel tradisional: eksistensi $=$ 0,59keputusan $+0,5$ produk - 0,078harga - 0,085tempat $+0,49$ dengan nilai $R^{2}=0,51$ artinya eksistensi ritel tradisional di kecamatan Sumbawa di pengaruhi oleh variabel keputusan, produk, harga dan tempat sebesar 51\%, sisanya 49\% dipengaruhi oleh variabel yang lain. Sedangkan dari hasil analisa hipotesis diperoleh keputusan pembelian warga kecamatan Sumbawa pada ritel tradisional dipengaruhi oleh harga dan tempat, sedangkan eksistensinya dipengaruhi oleh variabel produk dan keputusan pembelian. Adapun faktor-faktor yang berpengaruh langsung terhadap eksistensi ritel tradisional di kecamatan Sumbawa adalah faktor produk dan faktor keputusan pembeli, sedangkan faktor-faktor yang berpengruh tidak langsung adalah faktor produk melalui faktor keputusan pembeli.
\end{abstract}

Kata kunci: Analisis Faktor,Ritel Tradisional, Eksistensi, SEM, LISREL.

\begin{abstract}
Currently, in the sub-district of Sumbawa, West Nusa Tenggara province, there are many modern retail shops that have become competitors to the existence of traditional retailers that have existed before. Therefore, the aim of this research is to analyze the factors that influence the existence of traditional retailers with the existence of modern retailers in Sumbawa sub-district. This study uses a quantitative approach to statistical analysis using path analysis. The data used in this study is primary data, which is obtained through distributing questionnaires. It is known that the total population of the Sumbawa sub district based on population data in 2019 is 61,518 people, so using the Slovin formula the number of samples for this study is at least 100 people (with an error rate of 10\%). From the analysis using SEM and LISREL software obtained a mathematical model for the existence of traditional retails: existence $=0.59$ decisions +0.5 products -0.078 price -0.085 place +0.49 with a value of $R^{2}=0.51$ means the existence of traditional retail in the sub-district Sumbawa is influenced by decision, product, Price, and place varies by $51 \%$, the remaining $49 \%$ is influenced by other variables. Meanwhile, from the results of the hypothesis analysis, it is found that the purchasing decisions of Sumbawa sub-district residents at traditional retail are influenced by price and place, while their existence is influenced by product variables and purchasing decisions. The factors that have a direct influence on the existence of traditional retail in the Sumbawa sub - district are product factors and buyer decision factors, while the factors that have an indirect effect are product factors through buyer's decision factors.
\end{abstract}

Keywords: Factor Analysis, Traditional Retail, Existence, SEM, LISREL.

${ }^{\text {*Corresponding author }}$ 


\section{Pendahuluan}

Kota Sumbawa Besar adalah ibu kota kabupaten Sumbawa yang berada di Provinsi Nusa Tenggara Barat (NTB). Bedasarkan data kependudukan di Pusat Badan Statistika Kabupaten Sumbawa bahwa jumlah penduduk kota Sumbawa Besar semakin meningkat, tercatat bahwa jumlah penduduk pada tahun 2016 adalah 445.503 jiwa. Meningkatnya kepadatan penduduk tersebut yang terus meningkat maka kebutuhan sehari-hari pun menjadi faktor penting. Hal tersebut membuat investor terus mengembangkan usahanya khusunya dalam bidang penyedia kebutuhan pokok yang bersifat modern seperti minimarket moderen atau bahkan supermarket.

Ritel tradisional dan modern mampu mewujudkan kemashlahatan dan kesejahteraan para masyarakat dan diharapkan keberlangsungan ritel tradicional maupun moderen dapat berjalan dengan seimbang, namun seiring dengan meningkat dan majunya perekonomian secara global, ritel modern saat ini sangat berkembang termasuk di Sumbawa (saat ini terdapat terdapat 21 toko Alfamart dan 5 Indomart yang beroperasi, telah memiliki ijin), dan mengalami dinamika kinerja pada ritel tradisional setelah kehadiran ritel modern. Menjamurnya toko retail modern seperti Alfamart dan Indomaret di Kabupaten Sumbawa kini menjadi sorotan masyarakat, terutama pedagang kios yang berada di sekitar pasar modern tersebut. Ritel Moderen tersebut dikhawatirkan akan menjadi pesaing dari pedagang-pedagang kecil (kios rumah tangga) yang selama ini hanya mengandalkan pembeli yang kebetulan lewat.

Berdasarkan pemberitaan dari Harian Samawa Rea (28/04/2016), bahwa terdapat sekelompok masyarakat yang tergabung dalam Aliansi Pedagang Ritel (APR) Kabupaten Sumbawa menggelar aksi demo menolak keberadaan Alfamart dan Indomaret. Warga menuntut keberadaan ritel moderen yang dapat berpotensi mematikan ekonomi usaha kecil. Berdasarkan pemberitaan tersebut, maka dapat disimpulkan bahwa keberadaan ritel moderen di kecamatan Sumbawa menjadi pesaing bagi eksistensi ritel tradisional.

Persaingan antara ritel tradisional dan ritel modern banyak mengundang perhatian segala kalangan, dikarenakan selalu menempatkan pihak ritel tradisional dalam tingkat yang lemah. Perbedaan karakteristik yang berbanding terbalik dengan semakin memperlemah keadaan ritel tradisional. Ketidakjelasan regulasi mengenai industri ritel, menambah berat upaya untuk melindungi ritel tradisional. Ruang lingkup persaingan antara ritel tradisional dan ritel modern meliputi faktor internal maupun faktor eksternal, yaitu meliputi keseluruhan atribut di dalam aspek kinerja, aspek preferensi konsumen, dan aspek regulasi. Aspek preferensi konsumen mencakup human resource (terkait pelayanan yang diberikan), merchandise, harga dan lokasi (Utomo, 2011).

Peran pemerintah sangat penting dalam masalah yang sedang dihadapi oleh ritel tradisional agar kinerja para pedagang kecil tidak menurun yaitu dengan melakukan penertiban terhadap pendirian gerai minimarket khususnya Indomaret dan Alfamart. Sebagaimana Perpres No. 112/2007 tentang penataan dan pembinaan pasar tradisional pusat perbelanjaan dan toko modern, sebagaimana yang terdapat pada pasal 1 ayat 12 yang tentang peraturan zona, yang diharapkan mampu melindungi pedagang tradisional. Begitu juga halnya yang terdapat dalam UndangUndang No. 9 tahun 1995 tentang usaha kecil dalam pasal 8 disebutkan bahwa pemerintah harus menjaga iklim usaha dalam kaitannya dengan persaingan, dengan membuat peraturan-peraturan yang diperlukan. Bupati Sumbawa juga mengeluarkan peraturan tentang penataan dan pembinaan toko swalayan yaitu pada Peraturan Bupati Sumbawa No. 31 Tahun 2015. Untuk dapat melindungi usaha kecil, pemerintah mencegah terjadinya penguasaan pasar dan pemusatan usaha oleh orang perseorangan atau Kelompok tertentu yang dapat merugikan usaha kecil.

Beberapa penelitian tentang analisa keberadaan ritel moderen di kecamatan Sumbawa pernah dilakukan oleh Amri et al (2017), dimana pada penelitian tersebut dianalisis perbandingan jumlah laba pedagang kelontong setelah adanya ritel moderen adapun metode statistika yang digunakan adalah uji t, diperoleh hasil penelitian bahwa keuntungan yang diperoleh oleh warung kelontong mengalami penurunan. Penelitian yang dilakukan oleh Hermanto \& Suarantalla (2020), pada 
penelitian tersebut populasinya adalah mahasiswa program studi Teknik Industri Universitas Teknologi Sumbawa digunakan untuk menganalisa apakah terdapat perubahan minat belanja mahasiswa mahasiswa Teknik Industri dianalisis menggunakan uji Wilcoxon, dari hasil penelitian diperoleh bahwa tidak ada perubahan minat mahasiswa program studi Teknik Industri Universitas Teknologi Sumbawa berbelanja pada ritel tradisional setelah adanya ritel moderen di sekitar kampus. Dimana penelitian yang dilakukan oleh Hermanto \& Suarantalla (2020) diaplikasikan oleh Suarantalla (2020) pada populasi yang lebih luas yaitu warga kecamatan Sumbawa, hasil dari penelitian tersebut adalah terdapat pengaruh perubahan minat belanja warga pada ritel tradisional setelah adanya ritel moderen. Oleh karena itu, berdasarkan hasil dari tiga penelitian mengenai pengaruh ritel moderen terhadap eksistensi ritel taradisional yang pernah dilakukan di kecamatan Sumbawa maka pada penelitian ini dilakukan penelitian lebih lanjut mengenai hasil dari penelitian tersebut dan berdasarkan persoalan-persoalan yang telah dipaprkan sebelumnya, yaitu untuk mengetahui faktor-faktor apa saja yang dapat mempengaruhi eksistensi ritel tradicional di kecamatan Sumbawa, adapun metode yang digunakan adalah Structural Equation Modeling (SEM) dengan menggunakan software LISREL dan menggunakan SPSS. Selain menentukan faktor-faktor yang mempengaruhi eksisstensi ritel tradisional. Hermanto et al., (2020) menggunakan SEM dan LISREL untuk mengetahui faktor-faktor yang mempengaruhi kepuasan mahasiswa terhadap pelayanan administrasi di Fakultas Teknik, Universitas Teknologi Sumbawa.

\section{Metode Penelitian}

\subsection{Jenis Penelitian}

Dalam penelitian ini, jenis penelitian yang digunakan adalah penelitian kuantitatif, yaitu menguraikan sifat-sifat dari suatu keadaan untuk mengetahui faktor-faktor yang mempengaruhi eksistensi ritel tradisional di kecamatan Sumbawa setelah adanya ritel moderen.

\subsection{Model Penelitian SEM}

Menurut Viloria (2019), Structural Equations Models (SEM) adalah menentukan hubungan ketergantungan atau independensi variabel melalui integrasi persamaan linier. Perhatikan contoh SEM pada gambar 1 berikut ini (Edi Riadi, 2016).

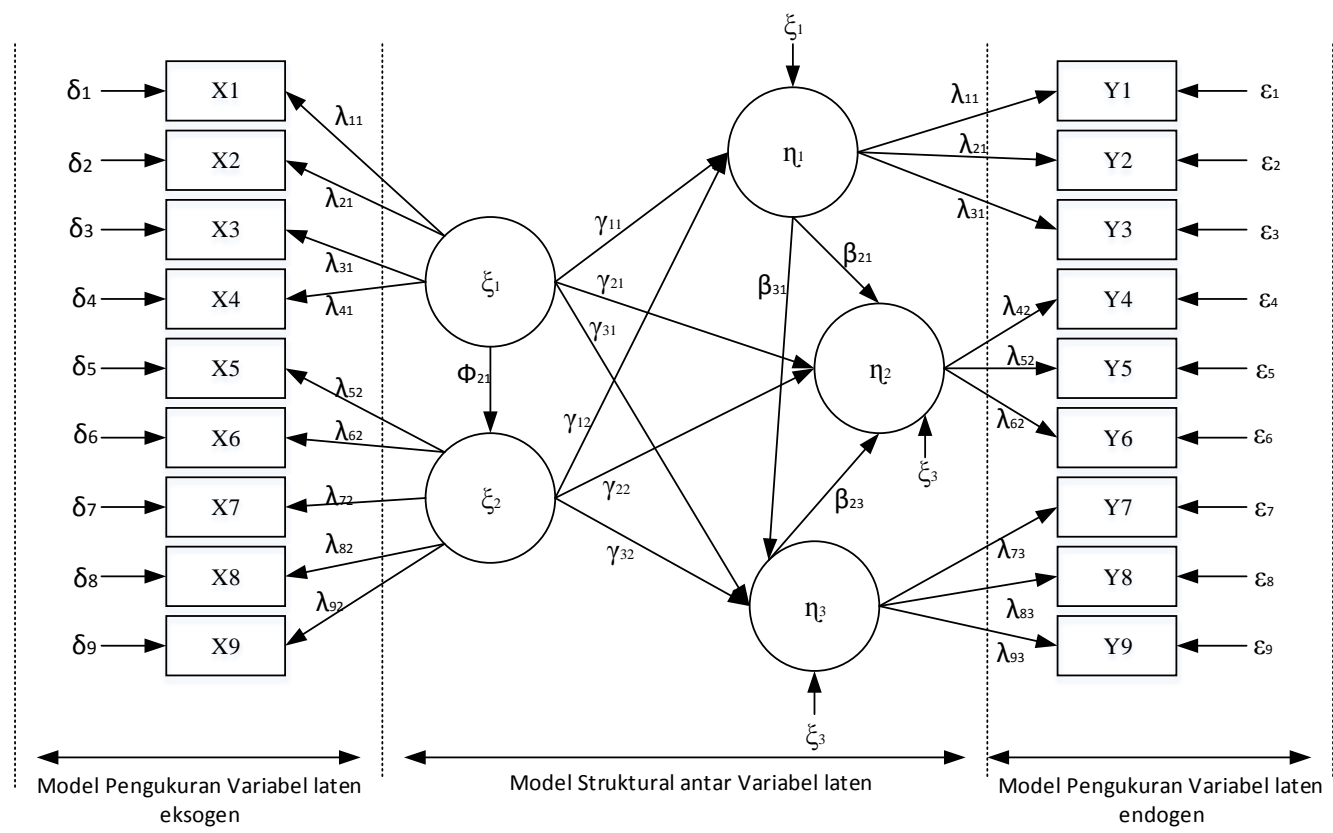

Gambar 1. Contoh Structural Equations Models

Berdasarkan gambar 1 terllihat bahwa SEM terbagi menjadi dua bagian utama yaitu model pengukuran variabel laten (eksogen dan endogen) dan model struktural antar variabel laten. Pada 
SEM terdapat dua varibel yang digunakan yaitu variabel laten dan variabel indikator. Dimana variabel laten dikelompokan menjadi dua yaitu variabel laten eksogen dan variabel laten endogen. Variabel laten eksogen berupa variabel yang identik dengan variabel bebas (independent), variabel-variabel yang menyebabkan fluktuasi nilai variabel laten lainnya di dalam suatu model. Varibel laten endogen identik dengan variabel terikat (dependent) oleh karena itu, variabel endogen dipengaruhi oleh varibel eksogen dalam model, baik secara langsung maupun tidak langsung. Sedangkan variabel indikator didefinisikan sebagai variabel yang besarannya dapat ditentukan secara langsung (Edi Riadi, 2016).

Berdasarkan contoh yang diberikan pada gambar 1, dengan menggunakan SEM maka ada dua jenis persamaan pada penelitian ini yaitu persamaan konstruk endogen dan persamaan konstruk eksogen yang disajikan pada table 2 (Hassneen et al., 2019).

Tabel 1. Persamaan Konstruk Endogen dan Eksogen

\begin{tabular}{cc}
\hline Konstruk Endogen & Konstruk Eksogen \\
\hline$Y_{1}=\lambda_{11} \eta_{1}+\varepsilon_{1}$ & $X_{1}=\lambda_{11} \xi_{1}+\delta_{1}$ \\
$Y_{2}=\lambda_{21} \eta_{1}+\varepsilon_{2}$ & $X_{2}=\lambda_{21} \xi_{1}+\delta_{2}$ \\
$Y_{3}=\lambda_{31} \eta_{1}+\varepsilon_{3}$ & $X_{3}=\lambda_{31} \xi_{1}+\delta_{3}$ \\
$Y_{4}=\lambda_{42} \eta_{2}+\varepsilon_{4}$ & $X_{4}=\lambda_{41} \xi_{1}+\delta_{4}$ \\
$\vdots$ & $\vdots$ \\
$Y_{8}=\lambda_{83} \eta_{3}+\varepsilon_{8}$ & $X_{8}=\lambda_{82} \xi_{2}+\delta_{8}$ \\
$Y_{9}=\lambda_{93} \eta_{3}+\varepsilon_{9}$ & $X_{9}=\lambda_{92} \xi_{2}+\delta_{9}$ \\
\hline
\end{tabular}

\section{Dimana}

$Y_{i}, X_{i} \quad$ : variabel-variabel teramati (observed variables) $, i=1,2, \ldots, 9$

$\eta_{m}, \xi_{m}$ : variabel-variabel tidak teramati (latent variables), $m=1,2, \ldots, 4$

$\lambda_{n m} \quad$ : koefisien variabel laten, $n=1,2, \ldots, 9 ; m=1,2,3$;

$\varepsilon_{i}, \delta_{i} \quad$ : error, $i=1,2, \ldots, 9$.

Secara teoritis konsep SEM merupakan konsep perkembangan dari análisis regresi berganda dan konsep análisis jalur. Setelah melalui análisis korelasional terdapat hubungan linier linier variabel $X_{i}$ dengan variabel $Y_{i}$ mengikuti pola regresi sebagai berikut (Edi Riadi, 2016).

$Y=a+b_{1} x_{1}+b_{2} x_{2}+\cdots+b_{n} x_{n}+e$

Dimana

$Y$ : variabel terkat;

$x_{i}$ : variabel bebas;

$a$ : konstanta;

$b_{i}:$ koefisien variabel terikat, $i=1,2, \ldots, n$.

\subsection{Identifikasi Variabel}

Pada penelitian ini variabel laten endogen adalah variabel keputusan pembeli sedangkan variabel eksogenya adalah faktor produk, faktor harga, faktor tempat penjualan. Sedangkan untuk variabel laten endogen adalah variabel Eksistensi maka variabel eksogenya adalah faktor produk, faktor harga, faktor tempat penjualan dan keputusan pembeli. Pada tabel 2 disajikan varibael laten dan variabel indikator berdasarkan penelitian Fauza (2017). 
Tabel 2. Identifikasi Variabel Penelitian

\begin{tabular}{|c|c|c|}
\hline Variabel Laten & & Variabel Indikator \\
\hline \multirow{5}{*}{$\begin{array}{l}\text { Variabel faktor produk } \\
\left(x_{1}\right)\end{array}$} & $\mathrm{X} 1.1$ & Tersedianya produk yang diperlukan pada ritel tradicional \\
\hline & $\mathrm{X} 1.2$ & Berbagai variasi produk dijual pada ritel tradicional \\
\hline & $\mathrm{X} 1.3$ & Barang-barang ditawarkan pada ritel tradisional berkualitas \\
\hline & $\mathrm{X} 1.4$ & $\begin{array}{l}\text { Barang dapat dikembalikan jika terdapat kerusakan pada } \\
\text { ritel tradicional }\end{array}$ \\
\hline & $\mathrm{X} 1.5$ & $\begin{array}{l}\text { Terjaga kebersihannya pada kemasan produk di ritel } \\
\text { tradisional }\end{array}$ \\
\hline \multirow{5}{*}{$\begin{array}{l}\text { Variabel faktor harga } \\
\left(x_{2}\right)\end{array}$} & $\mathrm{X} 2.1$ & $\begin{array}{l}\text { Ritel tradicional meneapkan harga sesuai dengan kualitas } \\
\text { barang yang ditawarkan }\end{array}$ \\
\hline & $\mathrm{X} 2.2$ & $\begin{array}{l}\text { Harga yang ditawarkan pada ritel ttradisional lebih murah } \\
\text { dibandingkan pada ritel moderen }\end{array}$ \\
\hline & $\mathrm{X} 2.3$ & $\begin{array}{l}\text { Mendapat potongan harga jika membeli dalam jumlah } \\
\text { banyak pada ritel tradisional }\end{array}$ \\
\hline & $\mathrm{X} 2.4$ & Pada ritel tradisional dapat melakukan tawar menawar harga \\
\hline & $\mathrm{X} 2.5$ & $\begin{array}{l}\text { Pembayaran pada ritel tradicional dapat dilakukan dengan } \\
\text { cara hutang }\end{array}$ \\
\hline \multirow{5}{*}{$\begin{array}{l}\text { Variabel faktor tempat } \\
\text { penjualan }\left(x_{3}\right)\end{array}$} & $\mathrm{X} 3.1$ & Tempat penjualan aman dan nyaman pada ritel tradicional \\
\hline & $\mathrm{X} 3.2$ & Tempat penjualan pada ritel tradisional bersih \\
\hline & $\mathrm{X} 3.3$ & Lokasi ritel tradisional dekat dengan rumah \\
\hline & $\mathrm{X} 3.4$ & $\begin{array}{l}\text { Lokaasi ritel tradisional mudah dijangkau dengan } \\
\text { menggunaka transportasi }\end{array}$ \\
\hline & $\mathrm{X} 3.5$ & Tersedianya área parkir pada ritel tradicional \\
\hline \multirow{5}{*}{$\begin{array}{l}\text { Variabel keputusan } \\
\text { pembeli }(y)\end{array}$} & Y1.1 & $\begin{array}{l}\text { Adanya minat dari diri sendiri untuk memilih ritel } \\
\text { tradicional }\end{array}$ \\
\hline & Y1.2 & $\begin{array}{l}\text { Keputusan memilih ritel tradisional karena ingin } \\
\text { terpenuhinya kebutuhan }\end{array}$ \\
\hline & Y1.3 & $\begin{array}{l}\text { Keputusan memilih ritel tradisional karena lokasi dekat } \\
\text { dengan rumah }\end{array}$ \\
\hline & Y1.4 & Keputusan memilih ritel tradisional karena proses cepat \\
\hline & Y1.5 & $\begin{array}{l}\text { Keputusan memilih ritel tradisional karena ingin } \\
\text { meningkatkan sosial. }\end{array}$ \\
\hline \multirow{5}{*}{ Variabel Eksistensi $(z)$} & Y2.1. & Usaha ritel tradisional telah berlangsung lama \\
\hline & Y2.2 & $\begin{array}{l}\text { Adanya Ritel Moderen, Ritel tradisional tetap } \\
\text { bertahan/berjalan }\end{array}$ \\
\hline & Y2.3 & $\begin{array}{l}\text { Ritel tradisional Bertambah luas/lebar dalam menjalankan } \\
\text { usahanya }\end{array}$ \\
\hline & Y2.4 & $\begin{array}{l}\text { Konsumen tetap berbelanja pada ritel tradisional tanpa } \\
\text { adanya iklan untuk meningkatkan hubungan kekeluargaan }\end{array}$ \\
\hline & Y2.5 & $\begin{array}{l}\text { Adanya pembelian ulang/rutin oleh konsumen pada Ritel } \\
\text { tradicional }\end{array}$ \\
\hline
\end{tabular}

\subsection{Teknik Pengumpulan Data}

Populasi dalam penelitian ini adalah warga kecamatan Sumbawa yang terdiri dari 62.763 jiwa. Sehingga dengan menggunakan formula Slovin dengan tingkat error 10\% diperoleh minimal sampel yang diperlukan dalam penelitian ini adalah 100 orang. Data yang diperoleh dalam penelitian ini yaitu data primer, dilakukan dengan cara menyebarkan lembar form kuisioner secara langsung kepada warga kecamatan Sumbawa sebanyak 126 orang. Tujuan dari penyebaran kuisioner tersebut adalah untuk mengetahui tingkat setuju warga kecamatan Sumbawa terhadap variabel-variabel indikator. Dalam pengisian kuisioner diukur dengan menggunakan skala likert (Taghizadeh \& Khalili, 2019), terdapat lima penilaian terdiri atas sangat setuju, setuju, tidak setuju dan sangan tidak setuju. Jika responden memilih Sangat Setuju (SS) maka diberi bobot 5, 
jawaban Setuju (S) diberi bobot 4, jawaban Kurang Setuju (KS) diberikan bobot 3, jawaban Tidak Setuju (TS) diberi bobot 2 jawaban Sangat Tidak Setuju (STS) diberi bobot 1 (Jeong et al., 2020).

\subsection{Pengujian Instrumen}

Pengujian pertama yang dilakukan dalam uji instrumen pada data hasil kuisioner adalah uji asumsi klasik berupa uji normalitas, uji heteroskedastisitas, dan uji multikolinearitas. dilakukan uji normalitas, berfungsi untuk menguji apakah dalam sebuah model regresi, variabel pengganggu memiliki distribusi normal (Ayuwardani, 2018). Dalam penelitian ini akan digunakan uji normalitas dengan menggunakan LISREL 8.8 dengan menggunakan taraf signifikansi 0,05. Data dinyatakan berdistribusi normal jika signifikansi lebih besar dari 0,05. Kemudian dilakukan uji heteroskedastisitas bertujuan untuk menguji apakah pada model regresi terjadi ketidak samaan varian dari residual satu pengamatan ke pengamatan lain. Jika varian dari nilai residual satu pengamatan ke pengamatan lain tetap, maka disebut dengan Homokedastisitas. Dan jika varian berbeda dari satu pengamatan ke pengamatan lain, maka di sebut Heteroskedastisitas. Dengan begini model regresi yang baik adalah yang terjadi homoskedastisitas (Yuwono et al., 2017). Jika probabilitas signifikasinya diatas tingkat kepercayaan 5\% atau diatas 0,05 maka model regresi tidak mengandung adanya heteroskedastisitas (Ningsih \& Assandimitra, 2017). Dan yang terakhir dilakukan uji multikolinearitas, bertujuan untuk menguji apakah model regresi ditemukan adanya korelasi antar variabel bebas. Model regresi yang baik seharusnya tidak terjadi korelasi di antara variabel independen. Pendeteksian ada atau tidaknya multikolinieritas dilakukan dengan melihat nilai VIF. Apabila nilai VIF < 10, maka model regresi bebas dari multikolinieritas (Denziana et al., 2014).

Pengujian instrumen juga dilakukan pada SEM yang telah diperoleh dari tahapan analisa penelitian, yaitu uji validitas instrumen, uji construct reliability $(C R)$, uji rata-rata variance extracted ( $A V E$ ) dan selanjutnya dilakukan pengujian apakah model yang diusulkan memmiliki kesesuaian ( $f i t$ ) dengan data sampel atau tidak. Menurut Hair et al., (2018) SEM dikatakan valid jika nilai standardized loading factor $(\lambda)$ lebih besar dari 0,5 atau idealnya lebih besar dari 0,7. Nilai $C R$ yang masih dapat diterima adalah 0,5 dan idealnya 0,7 . Sedangkan untuk nilai $A V E$ lebih besar dari 0,7 sangat bagus sedangkan di atas 0,5 masih dapat diterima. Menentukan nilai $C R$ dan $A V E$ berturut-turut dapat ditentukan dengan menggunakan persamaan (2) dan persamaan (3) (Bollen \& J. Scotth Long, 1993) dan (G. David Garson, 2011).

$$
C R=\frac{\left(\sum_{i=1}^{n} \lambda_{y i}\right)^{2}}{\left(\sum_{i=1}^{n} \lambda_{y t}\right)^{2}+\left(\sum_{i=1}^{n} \operatorname{var}\left(\varepsilon_{i}\right)\right)}
$$

\section{Dimana:}

$C R$ : indek reliabilitas komposit;

$\lambda_{y}:$ Standardized loading faktor;

$\operatorname{var}\left(\varepsilon_{i}\right)$ : varians error pengukuran.

$$
A V E=\frac{\sum_{i=1}^{n} \lambda_{i}^{2}}{n}
$$

\section{Dimana:}

$A V E$ : rata-rata ekstrak varians;

$\lambda_{i}:$ standardized loading faktor ke- $i$;

$n$ : jumlah ítem.

Selanjutnya dilakukan uji kesesuaian denga data sampel kriteria kelayakan model, jika nilai loading factor setiap variabel laten dengan variabel indikator dan antar variabel laten masingmasing nilainya lebih besar dari 0,5 , nilai chi-Square kurang dari chi-square tabel maka sudah fit, 
dan nilai df (degree of freedom) lebih besar dari 0 sudah fit, nilai $P$-value lebih dari 5\% sudah fit sedangkan nilai RMSEA lebih besar dari 5\% sudah fit (Jirangkul, 2020).

\subsection{Koefisien Determinasi $\left(\mathbf{R}^{2}\right)$}

Menururt Carl F. Gauss (dikutip dalam Siwi et al., 2019) bahwa koefisien Determinasi $\left(\mathrm{R}^{2}\right)$ digunakan untuk melihat besarnya pengaruh variabel bebas terhadap variabel terikat. Nilai koefisien determinasi $\left(\mathrm{R}^{2}\right)$ yang mendekati satu berarti variabel independennya menjelaskan hampir semua informasi yang dibutuhkan untuk memprediksi variabel dependen. Dimana niali $\mathrm{R}^{2}$ yang diperoleh mendekati satu, maka akan dapat dikatakan semakin kuat pengaruh variabel bebas terhadap variabel terikat. Sebaliknya, dimana $\left(\mathrm{R}^{2}\right)$ semakin mendekati nol, maka semakin lemah pengaruh variabel bebas terhadap variabel tidak bebas. Koefisien determinasi yang digunakan, yaitu Adjusted R Square.

\subsection{Hipotesis Penelitian}

Penyusunan hipótesis pada penelitian ini dibagi menjadi dua yaitu hipotesis pengaruh langsung dan hipotesis pengaruh tidak langsung (Fauza, 2017).

a. Hipotesis pengaruh langsung adalah sebagai berikut:

$\mathrm{H}_{1 \mathrm{a}}$ : Produk berpengaruh terhadap keputusan pembelian

$\mathrm{H}_{0 \mathrm{a}}$ : Produk tidak berpengaruh terhadap keputusan pembelian

$\mathrm{H}_{1 \mathrm{~b}}$ : Produk berpengaruh terhadap Eksistensi ritel tradisional

$\mathrm{H}_{0 \mathrm{~b}}$ : Produk tidak berpengaruh terhadap Eksistensi ritel tradisional

:

$\mathrm{H}_{1 \mathrm{f}}$ : Tempat berpengaruh terhadap Eksistensi ritel tradisional

$\mathrm{H}_{\mathrm{of}}$ : Tempat tidak berpengaruh terhadap Eksistensi ritel tradisional

b. Hipotesis pengaruh tidak langsung adalah sebagai berikut:

$\mathrm{H}_{1 \mathrm{~g}}$ :Keputusan pembelian menjadi variabel mediasi faktor produk yang mempengaruhi eksistensi ritel tradisional.

$\mathrm{H}_{0 \mathrm{~g}}$ : Keputusan pembelian menjadi variabel mediasi faktor produk yang tidak mempengaruhi eksistensi ritel tradisional.

$\mathrm{H}_{\mathrm{hh}}$ : Keputusan pembelian menjadi variabel mediasi faktor harga yang mempengaruhi eksistensi ritel tradisional.

$\mathrm{H}_{0 \mathrm{~h}}$ : Keputusan pembelian menjadi variabel mediasi faktor harga yang tidak mempengaruhi eksistensi ritel tradisional.

$\mathrm{H}_{\mathrm{li}}$ : Keputusan pembelian menjadi variabel mediasi faktor tempat yang mempengaruhi eksistensi ritel tradisional.

$\mathrm{H}_{0 \mathrm{i}}$ : Keputusan pembelian menjadi variabel mediasi faktor tempat yang tidak mempengaruhi eksistensi ritel tradisional.

Sedangkan untuk mengetahaui kekuatan pengaruh tidak langsung dari variabel-variabel dalam penelitian ini dilakukan dengan menggunakan uji Sobel (dikutip dalam Saputra \& Ardani, 2017) dengan menggunakan persamaan (4) berikut.

$$
Z=\frac{a b}{\sqrt{a^{2} S_{b}^{2}+b^{2} S_{a}^{2}+S_{a}^{2} S_{b}^{2}}}
$$

$$
\begin{aligned}
& \text { Dimana: } \\
& \begin{aligned}
S_{a}=\text { standar error koefisien } \mathrm{a} ; & a=\text { koefisien jalur } X_{i} \text { terhadap } Y_{i} \\
S_{b}=\text { standar error koefisien } \mathrm{b} ; & b=\operatorname{koefisien} \text { jalur } Y_{i} \text { terhadap } Y_{j}
\end{aligned}
\end{aligned}
$$




\section{Hasil dan Pembahasan}

\subsection{Uji Asumsi Klasik}

Kuisioner yang dilakukan pada warga kecamatan Sumbawa guna mengetahui faktor-faktor yang mempengaruhi eksistensi ritel tradisional stelah adanya ritel moderen. Adapun hasil kuisionernya disajikan dalam bentuk grafik dapat dilihat pada gambar 2 .

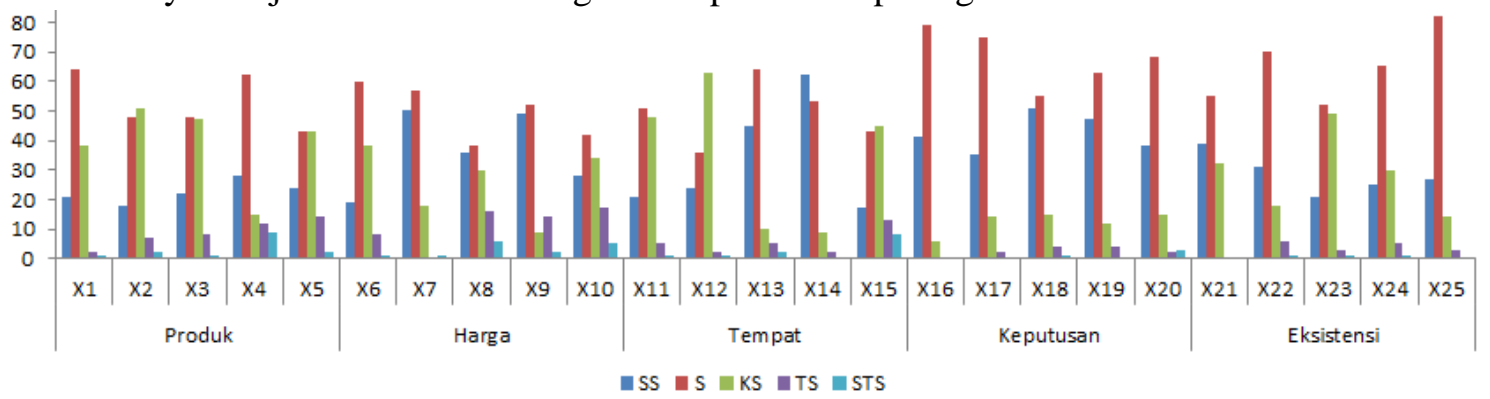

Gambar 2. Hasil Kuisioner

Gambar grafik pada gambar 2 merupakan model data hasil kuisioner, dimana pada gambar tersebut pada setiap variabel indikator (X1 sampai X25) masing-masing variabel faktor disajikan berapa jumlah warga yang sangat setuju (SS), setuju (S), Kurang setuju (KS), tidak setuju (TS) dan sangat setuju (STS) terhadapat pernyataan pada masing-masing variabel indikator. Data pada gambar 2 dilakukan uji asumsi klasik. Pertama dilakukan uji multikolinearitas, dengan menggunakan SPSS diperoleh hasil análisis uji multikolinearitas seperti disajikan pada tabel 3.

Tabel 3. Hasil Uji Multikolonieritas

\begin{tabular}{llrrrr}
\hline \multirow{2}{*}{ No. } & \multirow{2}{*}{ Faktor } & \multicolumn{2}{c}{ Variabel keputusan } & \multicolumn{2}{c}{ Variabel eksistensi } \\
\cline { 3 - 6 } & & Tolerance & VIP & Tolerance & \multicolumn{1}{c}{ VIP } \\
\hline 1. & Tempat & 0,729 & 1,373 & 0,602 & 1,662 \\
2. & Harga & 0,865 & 1,156 & 0,797 & 1,255 \\
3. & Produk & 0,697 & 1,436 & 0,696 & 1,437 \\
4. & Keputusan & & & 0,685 & 1,461 \\
\hline
\end{tabular}

Berdasarkan Tabel 3, diperoleh nilai VIF untuk setiap variabel kurang dari 10 maka dapat disimpulkan bahwa data yang digunakan pada penelitian ini tidak bersifat multikolinieritas. Selanjutnya dengan menggunakan SPSS dilakukan uji heteroskedastisitas terhadap variabel keputusan dan variabel eksistensi seperti disajikan pada tabel 4.

Tabel 4. Hasil Uji Heterokedastisitas

\begin{tabular}{crrrrr}
\hline \multirow{2}{*}{ No. } & \multirow{2}{*}{ Faktor } & \multicolumn{2}{c}{ Variabel keputusan } & \multicolumn{2}{c}{ Variabel eksistensi } \\
\cline { 3 - 6 } & & \multicolumn{1}{c}{ T } & Sig. & \multicolumn{1}{c}{ T } & Sig. \\
\hline 1. & Produk & 3,259 & 0,535 & $-0,918$ & 0,361 \\
2. & Harga & $-0,622$ & 0,112 & $-0,345$ & 0,731 \\
3. & Tempat & 0,370 & 0,712 & $-0,131$ & 0,896 \\
4. & Keputusan & & & 1,324 & 0,188 \\
\hline
\end{tabular}

Berdasarkan tabel 4, diperoleh nilai signifikan untuk semua variabel lebih besar dari 5\% maka model regresi tidak mengandung adanya heteroskedastisitas.dan dilakukan uji terakhir untuk uji asumsi klasik adalah uji normalitas dengan menggunakan LSREL 8.8, adapun hasil análisis uji normalitas disajikan pada tabel 5 . 
Tabel 5. Hasil Uji Normalitas

\begin{tabular}{clc}
\hline No. & Faktor & $\begin{array}{c}\text { P-value Skweness } \\
\text { dan Kurtosis }\end{array}$ \\
\hline 1. & Produk & 0,960 \\
2. & Harga & 0,948 \\
3. & Tempat & 0,960 \\
4. & Keputusan & 0,883 \\
5. & Eksistensi & 0,862 \\
\hline
\end{tabular}

Berdasarkan tabel 5, diperoleh nilai P-value pada Skewness and Kurtosis lebih besar dari 0,05. Maka dapat disimpulkan data yang digunakan dalam penelitian ini berdistribusi normal.

\subsection{Analisis Indikator (Model Pengukuran)}

Pada penelitian ini Variabel Eksogen adalah eksistensi, keputusan; variabel endogen adalah keputusan, produk, harga, tempat sedangkan variabel indikator adalah butir-butir pertanyaan yang dilambangkan dengan X1.1, X1.2, ..,X1.5, X2.1, X2.2, .., X2.5, X3.1, X3.2, .., X3.5, Y1.1, $\mathrm{Y} 1.2, \ldots, \mathrm{Y} 1.5$ dan Y2.1, Y2.2, ..., Y2.5. Langkah selanjutnya adalah menentukan variabelvaribel dan indikator-indikator yang layak untuk penyususnan model path diagram. Dari hasil hasil analisis diperoleh model fit untuk setiap indikator dan variabel dapat dilihat pada gambar 2 setelah dua kali melakukan pengujian proses. Jika pada pengujian terdapat loading factor yang nilainya kurang dari 0,5 maka variabel indikator tersebut akan dieliminasi dan diuji kembali tanpa varibel indikator tersebut. Proses pengujian berhenti setelah nilai loading factor lebih dari 0,5.

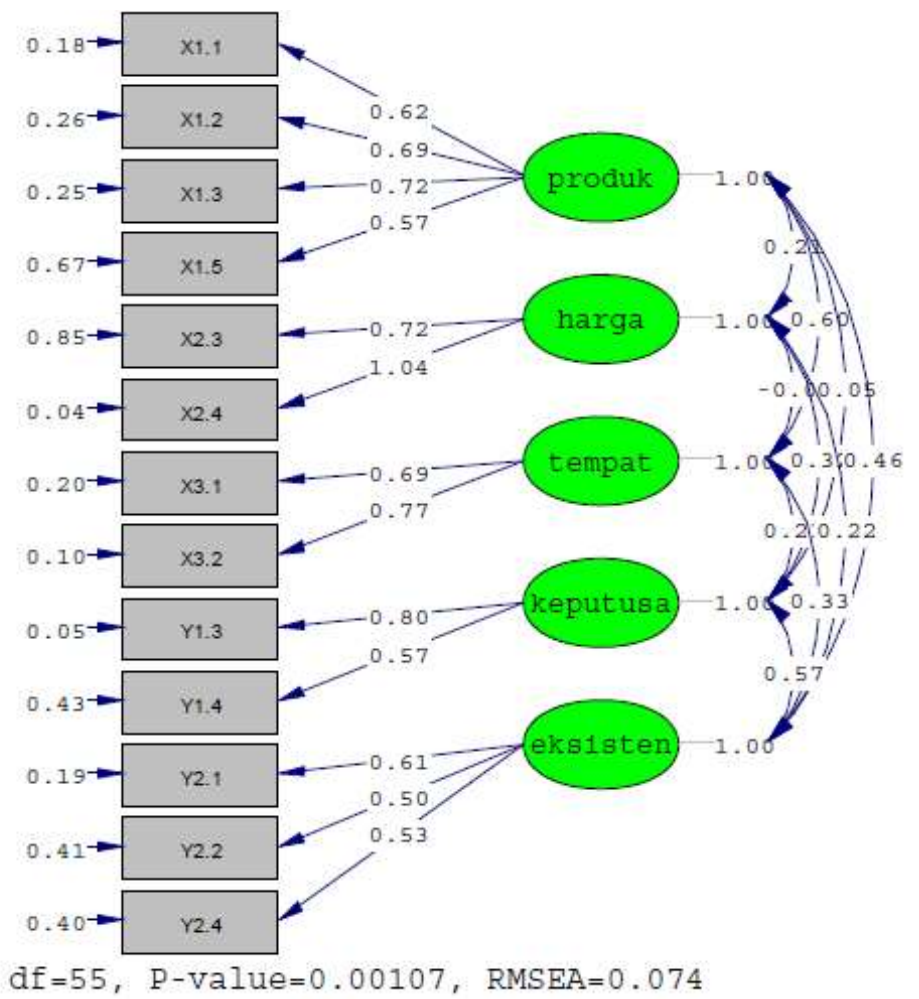

Gambar 3. Variabel dan indikator yang layak

Adapun hasil output LISRER pada path diagram mode Standardized Solution disajikan pada Gambar 4. 


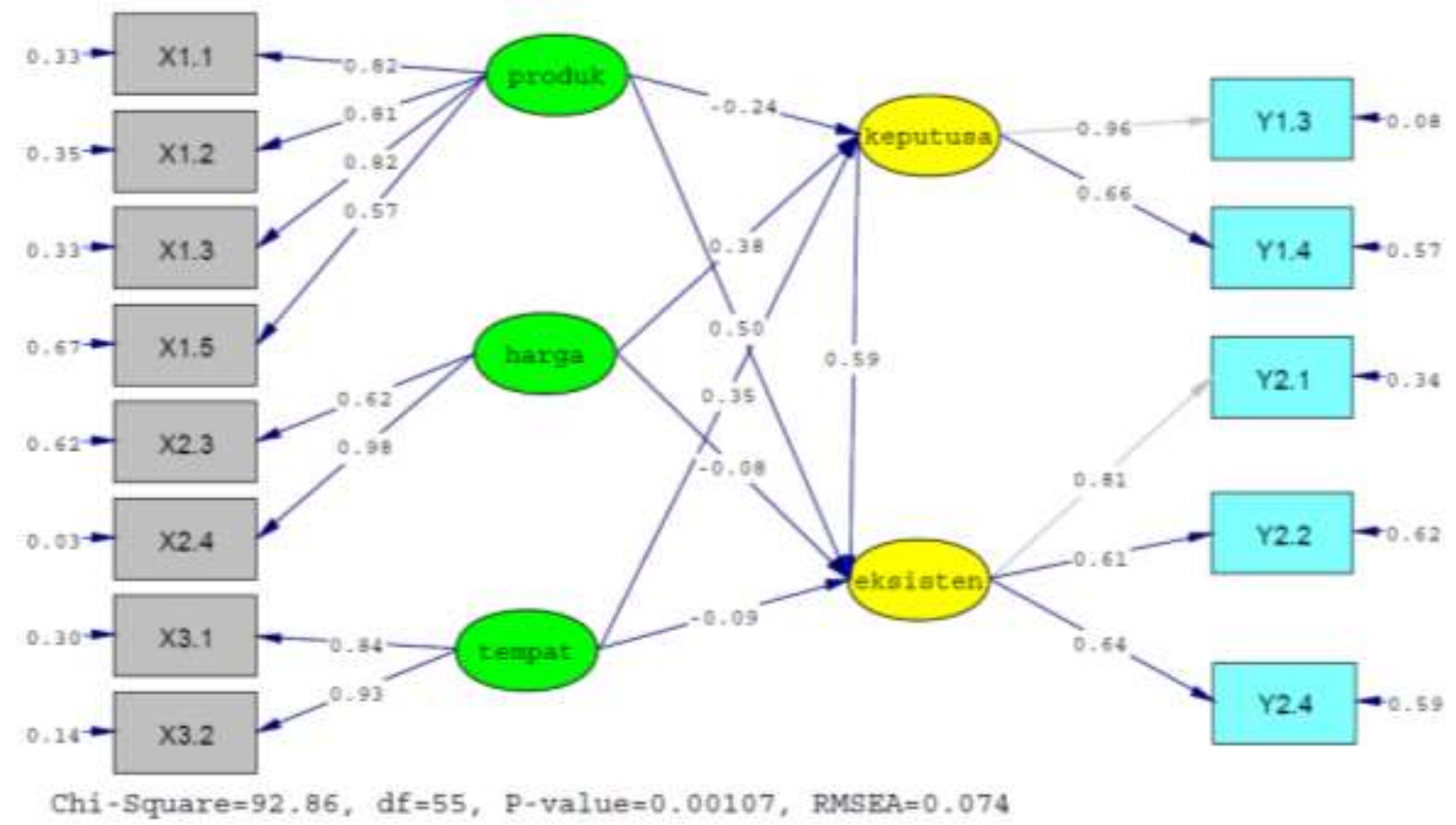

Gambar 4. Path model hasil analisis regresi berganda (standardzed Solution)

Berdasarkan gamabr 4, dapat dianalisis uji validitas instrumen, uji construct reliability (CR), uji rata-rata variance extracted (AVE). Dimana nilai loading faktor lebih besar dari 0,5 maka model tersebut valid. Berdasarkan persamaan (2) dan persamaan (3) diperoleh nilai CR dan AVE yang disajikan pada tabel 6 .

Tabel 6. Nilai CR dan AVE varibel Laten

\begin{tabular}{llll}
\hline No & Varibel Laten & CR & AVE \\
\hline 1. & Produk & 0,8 & 0,6 \\
2. & Harga & 0,8 & 0,7 \\
3. & Tempat & 0,9 & 0,8 \\
4. & Keputusan & 0,8 & 0,7 \\
5. & Eksistensi & 0,7 & 0,5 \\
\hline
\end{tabular}

Dapat dilihat pada tabel 6 nilai CR dan AVE pada setiap variabel lebih besar dari koefisien kritis yang ditetapkan $(0,5)$ maka dapat disimpulkan seluruh indikator masing-masing variabel laten produk, harga, tempat keputusan dan eksistensi seluruhnya reriabel.

Berdasarkan gambar 3 dapat dilihat bahwa model yang dihasilkan sudah baik, karena telah memenuhi kriteria kelayakan model. Loading factor nilainya lebih besar dari 0,5, nilai chi-Square adalah 92,86 kurang dari 93.17 (chi-square tabel) sudah fit, dan nilai df (degree offreedom) adalah 55 lebih besar dari 0 sudah fit, nilai $P$-value adalah 0,00107 kurang fit 5\% sedangkan nilai RMSEA adalah 0,074 lebih besar dari 5\% sudah fit (Jirangkul, 2020). Berdasarkan analisa jumlah kategori "fit" lebih banyak dari kategori "kurang fit" maka secara keselurusahan model sudah fit (Edi Riadi, 2016). Oleh karena itu variabel produk, tempat, harga, keputusan dan eksistensi dapat diguanakan untuk menyusun model regresi berganda.

\subsection{Analisis Model Persamaan Struktural (SEM)}

Langkah selanjunya adalah menentukan koefisien jalur untuk pengaruh total dan pengaruh tidak langsung., untuk Full Path Diagram SEM Standardized Solusion pada gambar 5 sebagai berikut. 


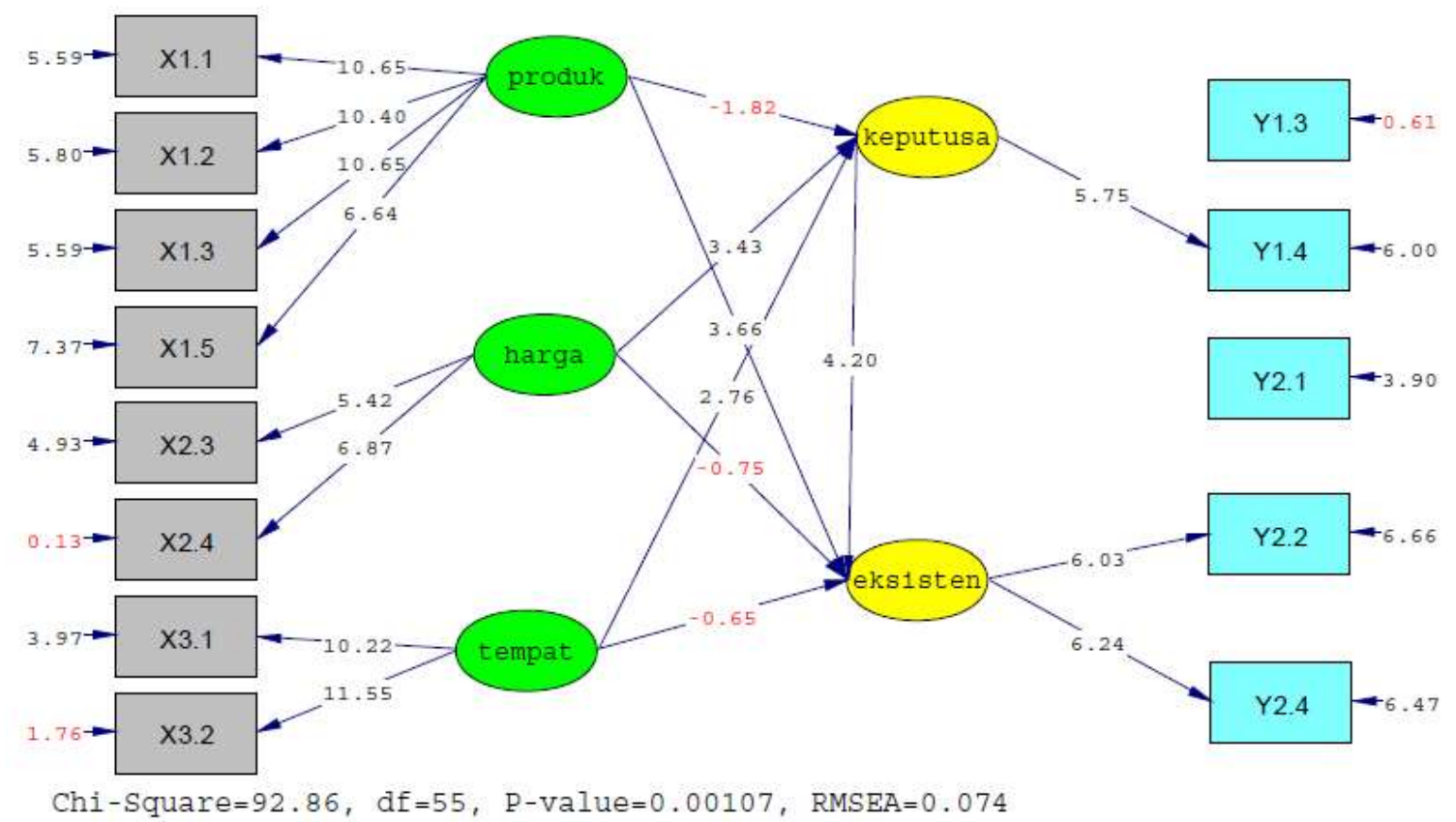

Gambar 5. Full Path Diagram SEM T-Value Solusion

Sedangkan hasil dari Structural Equation untuk model persamaan regresi linier berganda berdasarkan persamaan (1) untuk mengetahui pengaruh keputusan pembeli dan eksistensi dapat dilihat pada gambar 6 .

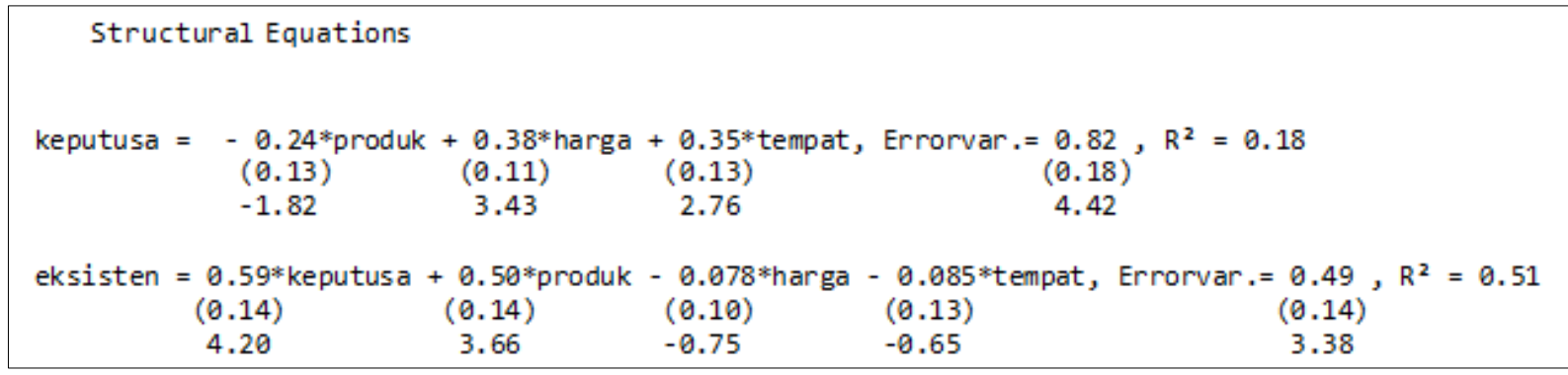

Gambar 6. output Structural Equation

Berdasarkan gambar 4, gambar 5 dan gambar 6 dapat dianalisa untuk variabel keputusan bahwa variabel produk berpengaruh terhadap variabel keputusan -0,24 dan standar error sebesar sebesar 0,13 , tetapi pengaruh tersebut tidak signifikan karena nilai $t_{\text {hitung }}$ sebesar $-1,82$ kurang dari nilai $t_{\text {tabel }} 1,98$. variabel harga berpengaruh terhadap variabel keputusan 0,38 dan standar error sebesar sebesar 0,11, berpengaruh secara signifikan karena nilai $t_{\text {hitung }}$ sebesar 3,43 lebih besar dari nilai $t_{\text {tabel }} 1,98$. Sedangkan variabel tempat berpengaruh terhadap variabel keputusan 0,35 dan standar error sebesar sebesar 0,13 , berpengaruh secara signifikan karena nilai $t_{\text {hitung sebesar } 2,76}$ kurang dari nilai tabel 1,98. Kemudian dari Gambar 5 untuk persamaan pertama yaitu persamaan variabel keputusan dapat dilihat nilai $\mathrm{R}^{2}$ sebesar 0,18 atau $18 \%$, variabel produk, harga dan tempat mempengaruhi variabel keputusan sebesar $18 \%$, sedangkan sisanya dipengaruhi oleh variabel lain.

Sedangkan untuk variabel eksistensi dipengaruhi oleh variabel keputusan sebesar 0,59 dengan standar error sebesar 0,14 , berpengaruh secara signifikan karena nilai $t_{\text {hitung }}$ sebesar 4,20 lebih besar dari nilai $t_{\text {tabel }} 1,98$, variabel produk mempengaruhi variabel eksistensi sebesar 0,50 dengan standar error sebesar 0,14, berpengaruh secara signifikan karena nilai $t_{\text {hitung }}$ sebesar 3,66 lebih besar dari nilai $t_{\text {tabel }} 1,98$, variabel harga mempengaruhi variabel eksistensi sebesar $-0,078$ dengan standar error sebesar 0,10, berpengaruh secara tidak signifikan karena nilai $t_{\text {hitung }}$ sebesar 
$-0,75$ kurang dari nilai tabel 1,98 , sedangkan variabel tempat mempengaruhi variabel eksistensi sebesar -0,085 dengan standar error sebesar 0,13, berpengaruh secara tidak signifikan karena nilai $\mathrm{t}_{\text {hitung }}$ sebesar $-0,65$ kurang dari nilai $\mathrm{t}_{\text {tabel }} 1,98$. Kemudian dari Gambar 6 untuk persamaan kedua dapat dilihat nilai $\mathrm{R}^{2}$ sebesar 0,51 atau $51 \%$, variabel produk, harga dan tempat mempengaruhi variabel keputusan sebesar $51 \%$, sedangkan sisanya dipengaruhi oleh variabel lain yang tidakdigunakan dalam penelitian ini.

Berdasarkan gambar 4 dapat disusun data tentang pengaruh langsung, pengaruh langsung dan pengaruh tidak langsung dari variabel keputusan dan variabel eksistensi seperti disajikan pada tabel 7. Dimana pengaruh total adalah penjumlahan dari pengaruh langsung dan pengaruh tidak langsung (Edi Riadi, 2016).

Tabel 7. Pengaruh Langsung dan pengaruh tidak langsung

\begin{tabular}{|c|c|c|c|c|c|c|}
\hline \multirow{2}{*}{ No. } & \multirow{2}{*}{$\begin{array}{l}\text { Hubungan } \\
\text { Struktural }\end{array}$} & \multirow{2}{*}{$\begin{array}{c}\text { Pengaruh } \\
\text { Langsung } \\
\text { (DCE) }\end{array}$} & \multicolumn{3}{|c|}{$\begin{array}{l}\text { Pengaruh Tidak Langsung } \\
\text { (ICE) melalui keputusan }\end{array}$} & \multirow{2}{*}{$\begin{array}{c}\text { Pengaruh } \\
\text { Total (TCE) }\end{array}$} \\
\hline & & & $\mathbf{G}$ & $\mathbf{B}$ & $\mathbf{G} \times \mathbf{B}$ & \\
\hline 1 & Produk-Keputusan & $-0,24$ & - & - & - & $-0,24$ \\
\hline 2 & Harga-Keputusan & 0,38 & - & - & - & 0,38 \\
\hline 3 & Tempat-keputusan & 0,35 & - & - & - & 0,35 \\
\hline 4 & Produk-Eksistensi & 0,50 & $-0,24$ & 0,59 & $-0,14$ & 0,38 \\
\hline 5 & Harga-Eksistensi & $-0,08$ & 0,38 & 0,59 & 0,22 & 0,14 \\
\hline 6 & Tempat-Eksistensi & $-0,09$ & 0,35 & 0,59 & 0,21 & 0,12 \\
\hline 7 & Keputusan-Eksistensi & 0,59 & - & - & - & 0,59 \\
\hline
\end{tabular}

Berdasarkan gambar 4 dapat ditentukan besar thitung untuk pengaruh-pengaruh langsung setiap variabel-variabel faktor terhadap variabel keputusan pembeli dan variabel eksistensi. Sedangkan berdasarkan gambar 4 dan persamaan (4) dapat ditentukan pengaruh-pengaruh tidak langsung setiap variabel-variabel faktor terhadap variabel eksistensi melalui variabel keputusan pembeli. Maka dari nilai uji $t_{\text {hitung }}$ perbandingan dengan $t_{\text {tabel }}=1,98$ dapat dilakukan pengujian hipotesis penelitian dapat dilihat pada tabel 8 .

Tabel 8. Hasil Pengujian Hipotesis Penelitian

\begin{tabular}{clcc}
\hline No. & \multicolumn{1}{c}{ Hipotesis } & $\boldsymbol{t}_{\boldsymbol{h i t u n g}}$ & Keputusan \\
\hline 1. & Produk berpengaruh terhadap keputusan pembelian & $-1,82$ & Ditolak \\
2. & Harga berpengaruh terhadap keputusan pembelian & 3,43 & Diterima \\
3. & Tempat berpengaruh terhadap keputusan pembelian & 2,76 & Diterima \\
4. & Produk berpengaruh terhadap eksistensi ritel tradisional & 3,66 & Diterima \\
5. & Harga berpengaruh terhadap eksistensi ritel tradisional & $-0,75$ & Ditolak \\
6. & Tempat berpengaruh terhadap eksistensi ritel tradisional & $-0,65$ & Ditolak \\
7. & Keputusan pembelian berpengaruh terhadap eksistensi ritel & 4,20 & Diterima \\
& tradisional & & \\
8. & Keputusan pembelian menjadi variabel mediasi faktor produk & 2,68 & Diterima \\
& yang mempengaruhi eksistensi ritel tradisional. & & \\
9. & Keputusan pembelian menjadi variabel mediasi faktor harga & $-0,72$ & Ditolak \\
& yang mempengaruhi eksistensi ritel tradisional. & \\
10. & Keputusan pembelian menjadi variabel mediasi faktor tempat & $-0,63$ & Ditolak \\
& yang mempengaruhi eksistensi ritel tradisional & \\
\hline
\end{tabular}

Berdasarkan hasil analisis yang disajikan pada tabel 8 maka dapat dijelaskan sebagai berikut.

a) $H_{1 a}$ ditolak karena $t_{\text {hitung }}=-1,82$ lebih kecil dibandingkan dengan $t_{\text {tabel }}=1,98$ maka dapat disimpulkan tidak terdapat pengaruh antara produk dengan keputusan pembelian di ritel tradisional. Oleh karena itu pedagang berusaha memenuhi kebutuhan konsumen melaui produk. 
b) $\mathrm{H}_{l b}$ diterima karena $t_{\text {hitung }}=3,43$ lebih besar dibandingkan dengan $t_{\text {tabel }}=1,98$, maka dapat disimpulkan terdapat pengaruh antara harga dengan keputusan pembelian di ritel tradisional.

c) $\mathrm{H}_{l c}$ diterima karena $t_{\text {hitung }}=2,76$ lebih besar dibandingkan dengan $t_{\text {tabel }}=1,98$, maka dapt disimpulkan terdapat pengaruh antara tempat dengan keputusan pembelian di ritel tradisional

d) $\mathrm{H}_{1 \mathrm{~d}}$ diterima karena nilai $t_{\text {hitung }}=3,66$ lebih besar dibandingkan dengan $t_{\text {tabel }}=1,98$, maka dapat disimpulkan terdapat pengaruh antara produk dengan eksistensi ritel tradisional.

e) $\mathrm{H}_{1 \mathrm{e}}$ ditolak karena nilai $t_{\text {hitung }}=-0,75$ lebih kecil dibandingkan dengan $t_{\text {tabel }}=1,98$, maka dapat dsimpulkan tidak terdapat pengaruh antara harga dengan eksistensi ritel tradisional.

f) $\mathrm{H}_{1 \mathrm{f}}$ ditolak karena nilai $t_{\mathrm{hitung}}=-0,65$ lebih kecil dibandingkan dengan $t_{\text {tabel }}=1,98$, maka dapat disimpulkan tidak terdapat pengaruh antara tempat dengan eksistensi ritel tradisional.

g) $\mathrm{H}_{1 \mathrm{~g}}$ di tolak karena nilai $t_{\text {hitung }}=4,20$ lebih besar dibandingkan dengan $t_{\text {tabel }}=1,98$, maka dapat disimpulkan terdapat pengaruh antara keputusan pembelian dengan eksistensi ritel tradisional.

h) $\mathrm{H}_{1 \mathrm{~h}}$ diterima karena nilai $\mathrm{t}_{\mathrm{hitung}}=2,68$, lebih besar dibandingkan dengan nilai $\mathrm{t}_{\text {tabel }}$ $=1,98$, maka dapat disimpulkan Keputusan pembelian menjadi variabel mediasi faktor produk yang tidak mempengaruhi eksistensi ritel tradisional.

i) $\mathrm{H}_{1 \mathrm{i}}$ ditolak karena nilai $\mathrm{t}_{\mathrm{abel}}=1,98$, maka dapatdisimpulkan Keputusan pembelian menjadi variabel mediasi faktor harga yang tidak mempengaruhi eksistensi ritel tradisional.

j) $\mathrm{H}_{1 \mathrm{j}}$ ditolak karena nilai $\mathrm{t}_{\mathrm{hitung}}-0,63$, lebih kecil dibandingkan dengan nilai $\mathrm{t}_{\mathrm{abel}}=1,98$, maka dapat disimpulkan keputusan pembelian menjadi variabel mediasi faktor tempat yang tidak mempengaruhi eksistensi ritel tradisional.

\section{Simpulan}

Berdasarkan hasil penelitian yang telah dilakukan maka dapat ditarik beberapa kesimpulan yaitu pada penelitian ini digunakan tiga variabel dijadikan faktor-faktor yang mempengaruhi keputusan pembeli serta pengaruhnya terhadap eksistensi ritel tradisional di kecamatan Sumbawa yaitu faktor produk, faktor harga dan faktor tempat. Namun dari ketiga faktor tersebut faktorfaktor yang mempengaruhi keputusan pembeli adalah faktor harga dan faktor tempat. Sedangkan faktor yang mempengaruhi eksistensi ritel tradisional secara tidak langsung adalah faktor produk atau Keputusan pembelian menjadi variabel mediasi faktor produk yang mempengaruhi eksistensi ritel tradisional.

\section{Ucapan Terima Kasih}

Tim peneliti mengucapkan terima kasih kepada Ditlitabmas Dirjen Dikti Kementerian dan Kebudayaan yang telah mendanai penelitian ini dalam skim Penelitian Dosen Pemula (PDP).

\section{Daftar Pustaka}

Amri, F., Jibrail, A., \& Surwadi, D. (2017). Nalisis Perbandingan Jumlah Laba Pedagang Kelontong Setelah Berdirinya Alfamart (Studi Kasus Di Kecamatan Sumbawa). Jurnal Ekonomi Dan Bisnis Indonesia, 02(02), 47-52.

Ayuwardani, R. P. (2018). The influence of financial and non-financial information to underpricing stock prices when innitial public offering (empirical study on go public companies the Indonesia stock exchange periode 2011-2015). Nominal, Barometer Riset Akuntansi Dan Manajemen, 7(1), 143-158. https://doi.org/10.21831/nominal.v7i1.19781

Bollen, K. A., \& J. Scotth Long. (1993). Testing structural equation models. Sage Focus Editions, 154. 
Denziana, A., Indrayenti, \& Fatah, F. (2014). Corporate Financial Performance Effects Of Macro Economic Factors Against Stock Return. Akuntasi \& Keuangan, 5(2), 17-20.

Edi Riadi. (2016). Statistik SEM - Structural Equation Modeling dengan Lisrel (E. Kurnia (ed.); 1 st ed.). Andi.

Fauza, M. (2017). Analisis Faktor yang Mempengaruhi Eksistensi Ritel Tradisional Dalam Menghadapi Ritel Moderen di Kecamatan Medan Amplas. At-Tawassuth, 2(1), 146-169.

G. David Garson. (2011). Structural Equation Modeling. http://faculty.chass.ncsu.edu/garson/PA765/structur.htm

Hair, J. F., Risher, J. J., \& Ringle, C. M. (2018). When to use and how to report the results of PLS-SEM. European Business Review, 31(1), 2-24. https://doi.org/10.1108/EBR-11-20180203

Hassneen, E., El-Abbasi, A. H., Khalifa, M., \& Shoaeb, F. (2019). Using a two-level structural equation model to study the determinants of reproductive behaviour in Giza Governorate. Egyptian Informatics Journal, 20(2), 143-150. https://doi.org/10.1016/j.eij.2019.02.001

Hermanto, K., \& Suarantalla, R. (2020). Analisis Minat Belanja Mahasiswa Teknik Industri UTS pada Ritel Tradisional dengan Adanya Ritel Moderen. In UNSA (Ed.), Prosiding Seminar Nasional IPPeMas 2020 (Issue 112, pp. 296-302). UNSA. http://journal.lppmunsa.ac.id/index.php/ippemas2020/article/view/170/166

Hermanto, K., Suarantalla, R., Utami, S. F., \& Sudirman. (2020). Application of SEM in analyzing student satisfaction with administrative services. Journal of Physics: Conference Series, 1663(1), 1-8. https://doi.org/10.1088/1742-6596/1663/1/012008

Jeong, B., Lee, J. Y., Kim, B. M., Park, E., Kwon, J. G., Kim, D. J., Lee, Y., Choi, J. S., \& Lee, D. (2020). Associations of personality and clinical characteristics with excessive Internet and smartphone use in adolescents: A structural equation modeling approach. Addictive Behaviors, 110(January), 106485. https://doi.org/10.1016/j.addbeh.2020.106485

Jirangkul, W. (2020). Structural equation modeling of best practice-based high-performance public organizations in Thailand. Kasetsart Journal of Social Sciences, 41(1), 124-129. https://doi.org/10.1016/j.kjss.2018.07.010

Ningsih, T. R., \& Assandimitra, N. (2017). Pengaruh Bid-Ask Spread, Market Value Dan Variance Return Terhadap Holding Period Saham Sektor Pertambangan Yang Listing Di Bursa Efek Indonesia (Bei) Tahun 2011-2015. Jurnal Ilmu Manajemen (JIM), 5(3).

Ramadiani, R. (2010). Structural Equation Model For Multivariate Analysis Using LISREL. Jurnal Informatika Mulawarman, 5(1), 14-18. https://doi.org/10.30872/jim.v5i1.48

Saputra, I., \& Ardani, I. (2017). Peran Brand Image Dalam Memediasi Pengaruh Green Marketing Terhadap Corporate Reputation. E-Jurnal Manajemen, 6(1), 87-115.

Siwi, M. D., Siswandari, \& Gunarhadi. (2019). The Correlation between Leadership, Motivation, Work Climate and High Economic Theachers' Performance in Karanganyar Regency. International Journal of Active Learning, 4(1), 45-58.

Suarantalla, R., Nur, M. A., \& Hermanto, K. (2020). Perubahan Jumlah Konsumen Ritel Tradisional Setelah Adanya Ritel Moderen di Kecamatan Sumbawa. Tambora, 4(3), 7-12.

Taghizadeh, M., \& Khalili, M. (2019). Engineering Students ' Academic Reading Comprehension: The Contribution of Attitude , Breadth and Depth of Vocabulary Knowledge. Iranian Journal of English for Academic Purposes, 8(1), 49-66.

Utomo, T. J. (2011). Persaingan Bisnis Ritel : Tradisional vs Modern (The Competition of Retail Business : Traditional vs Modern). Fokus Ekonomi, 6(1), 122-133.

Viloria, A., Lezama, O. B. P., \& Mercado, N. (2019). Model and simulation of structural equations for determining the student satisfaction. Procedia Computer Science, 160, 527531. https://doi.org/10.1016/j.procs.2019.11.053

Yuwono, A. K., Yuwono, B. D., \& Wijaya, A. P. (2017). Pembuatan Peta Zona Nilai Ekonomi Kawasan Pantau Parangtritis Berdasarkan Willingness to Pay Menggunakan Sistem Informasi Geografis. Geodesi Undip, 6(4), 128-137. 